\title{
Studies on vocal musical educational reformation in Chinese high normal university under the background of full implementation of new curriculum standard
}

\author{
Yaxiong Mao \\ College of Music, China West Normal University, Nanchong, 637009, China
}

Keywords: New curriculum standard, High normal university, Vocal music education, Teaching reform.

\begin{abstract}
With the issuance of new curriculum reform, vocal musical in high normal university has embraced new development upsurge. Researchers and high vocal musical teachers have conducted in-depth exploration on the educational concept, teaching method and ways, contents and other aspects of vocal musical education, and obtained a certain theoretical research achievements, and made great contribution to vocal musical educational reform in high normal university. But limited by some subjective and objective factors, there exist limitations and inadequacies in studies. Thus, it requires further exploration in high normal university's vocal musical education by combining with the reality, teaching practice on the basis of existing research achievements from different perspectives and levels so as to make contributions to the development of vocal musical education in Chinese high normal university.
\end{abstract}

\section{Introduction}

After entering into the 21st century, education scale, level, and system construction in Chinese high normal university has entered into high-speed development period with a fruitful theoretical research achievements obtained. But it does not mean that there is no problem in vocal musical teaching in high normal university, poor conditions of running a school, single mode of talent cultivation, backward teaching concept and material contents, insufficient teacher resource, unclear teaching objective, invalid and incomplete teaching course system are existing problem making talents cannot fully satisfy the demands of elementary vocal musical teaching practice in middle and primary schools. With the issuance and full implementation of "Standard of music course in full-time compulsory education", vocal musical teaching in middle and primary schools have entered into a new development period. Vocal musical teaching reform in high normal university has new development objective. With the demand of the times and educational development, vocal musical education in high normal university has attracted attention from the society, and exploration upsurge appears in vocal musical educational reform in high normal university.

\section{Reform of vocal musical teaching and educational concept in high normal university}

There must be a clear teaching objective in vocal musical education. The setting of teaching objective requires to connect vocal musical educators closely with signing teaching. It can be seen that, teacher-training of vocal musical education is the essence. Influenced by various subject and objective factors, vocal musical teacher's educational concept will automatically deviate from the cultivation objective in the process of vocal musical practical teaching. Some teachers just emphasize education professionalism but ignore the teacher-training quality of vocal musical teaching. This makes vocal musical teaching in high normal university cannot meet the standard of normal education. This problem has attracted researchers" great attention in long-term research process and they have strongly criticized this. Strengthen teacher-training quality has become the focus of vocal 
musical teaching in high normal university. In-depth studies on teaching activities balancing professionalism and teacher-training quality of vocal musical teaching have been conducted.

Li Jingyu believes that teacher-training quality as the essential problem of vocal musical teaching reform relates to the objective setting and fulfillment of vocal musical teaching. Xu Honglei believes that vocal musical education in normal university must be carried out by focusing on the direction of cultivating more eligible teachers for the society and middle and primary schools.

Handerson believes that oral emphasis of teacher-training quality is the approval of reducing teaching standard. Under this cognition, professionalism of vocal musical teaching will definitely reduce so that students cultivated are all-round talents instead of professional talents. So this cognition is obviously wrong. Cai Yuanhong believes that no matter professionalism or teacher-training quality is emphasized in vocal musical teaching in high normal university, or integration and supplementary of both must be implemented in the vocal musical course system setting and talent cultivation methods in vocal musical education.

From the educational concept, an important issue to be solved in current vocal and musical teaching in high normal university is "how to connect aesthetics into the whole process of vocal and musical teaching". Resercher Yan Feng believes that the current development situation of vocal musical teaching is far left behind from musical teaching reform in middle and primary schools and the requirement for musical teacher's professional ability. The gap with the educational concept of "focus on musical aesthetics" required by new curriculum standard is too large. Under the background of full implementation of new curriculum standard, vocal musical teaching in China should change skill training to guiding students' feeling, experiencing music. Cultivating student's musical appreciation ability, musical perceptivity, aesthetics ability should be the ultimate objective of vocal musical teaching in high normal university.

\section{Reform of vocal musical teaching method in high normal university}

Vocal musical teaching method is a hot point under heated discussion in vocal musical teaching reform. Researcher Gao Bing believes that one reason of vocal musical teching reform in high normal university is to obtain larger survival and development space and scale in high normal university. They continue expanding recruitment and finally the number of students increase sharply. Thus the conflict between insufficient teaching resource and heavy teaching task is getting more and more serious. Schools must take the method of vocal musical team teaching to replace traditional "one to one" teaching mode if they want to relieve the conflict. It can be seen from this that reform of vocal musical teaching in high normal university and teaching modes of team class and large class are necessary choice for high normal universities to develop in the times, as well as an expedient to effectively relieve the conflict between insufficient teaching resource and heavy teaching task. Traditional vocal musical teaching mode has great limitation which is another reason to reform the teaching methods in vocal musical education. Researcher Gui Hua beehives that the long-standing "one to one" teaching mode is to provide skill training for students and to cultivate student's singing ability. But it seldom involves vocal musical theoretical knowledge and pays no attention to cultivating students' teaching ability. The limited sensible accumulation cannot satisfy primary and secondary school students' actual demand for sound effect course study.

For team class and large class, the new type teaching pattern, some researchers have raised doubts as they think collective course means to simply divide a class based on the number of students. The teaching pattern just continues "one to one" teaching mode which cannot fully develop the advantages of collective courses and will shorten and waste students' limited class time, and reduce teaching quality. Behind the reform of vocal musical education in high normal university, there exist serious disadvantage of "change in form but not in content and method".

For the dispute, researcher Handerson believes that there should be no uniformed regulations of vocal musical teaching method in normal university. Reform should be conducted according to the teaching condition of the school in innovative and realistic teaching method. No matter which 
teaching method is used, high normal universities should fully stimulate and mobilize students' learning interest and activity, excavate their learning potential.

Currently, the teaching method large class, medium class and combined class exist in vocal musical education. No matter the praise is demanded in which way, it cannot be denied that the emerging of these new teaching method is the result that vocal musical teaching adapts to the requirement of the times and new curriculum standard. So the necessity of its existence is without doubt. Researcher Wang Lei believes that combining the teaching content for the purpose of cultivating students' professional quality with the teaching method of combining small and large courses can remain the advantages of skill training for "one-to-one" teaching mode and can also solve the problem of solving teacher shortage in vocal musical education.

\section{Reform of vocal musical teaching content in high normal university}

Almost all researchers hold critical attitude to the teaching content of "emphasizing skills but ignoring theory" in vocal musical class. "Theory" in the paper refers to the theoretical knowledge of vocal music performance and vocal musical teaching. From a macro-perspective, the teaching concept of "fundamental music education oriented, correct the incorrect teaching content of valuing skill, ignoring theories and teaching, construct the singing theory, singing skills, and singing education" has been widely recognized by all sectors of society. Under the background of new curriculum standard in full operation. Vocal musical teaching should be conducted for the purpose of cultivating talents with high professional quality and comprehensive ability singing, instructing, comparing and guiding, which is also the correct development direction of vocal musical teaching reform in Chinese high normal universities.

From a micro-perspective, every detailed teaching content in vocal musical teaching has a lot of value for loquacity exploration. Researcher Henderson believes that vocal musical skill teaching must be expanded on the basis of existing bel canto knowledge structure. The content should contain comprehensive bel canto singing, and contain folk style signing, traditional opera singing knowledge. Regarding the teaching content selection, researcher Yue Bingli believes that vocal musical teaching should incorporate local musical works into the content and actively promote national culture and highlight local and national characteristics.

Researcher Cai Yuanhong believes that vocal musical teaching theory course setting should not be for theoretical purpose but for providing a macro historic background for high normal university students and exploring innovative teaching method based on "teacher-training" nature of teaching so as to provide an up-to-date cultural background and continuously improve the signing cultural level of high normal university students.

Vocal musical teaching contents in high normal university should contain educational theoretical knowledge and teaching practical contents. From the achievements of vocal musical teaching obtained, researchers have seldom focused on the theoretical study. For the teaching contents, some scholars believes the content of new curriculum standard should be included into vocal musical teaching scope. Currently, Chinese high normal university vocalism students know little about the basic education reform knowledge and the dynamic of reform development dynamic. The problem has become a serious barrier for vocal musical educational reform in high normal university. Thus, vocal musical teaching should be connected with political, educational and cultural aspects so as to establish a sound, scientific and reasonable vocal knowledge system and keep up with the time and educational development.

\section{Reform of vocal musical teaching material, teaching method, and evaluation method in high normal university.}

Reform of vocal musical teaching material in high normal university. Currently, Chinese local and national musical works are not sufficiently excavated into teaching materials used in Chinese high normal university. Educational works set in teaching materials lack bright features and knowledge 
involved are not easy for teaching activities. Foreign vocal musical works are in single style without comprehensive contents. Under the background of new curriculum standard in full operation, teaching material construction must be with bright features. When choosing material content, vocal musical works with a broad coverage of diversified culture should be selected. Researcher Wang Xinhui believes that it is necessary to appropriately improve the artist nature of teaching materials and add some new songs with strong time spirit. Some scholars think reform of vocal musical teaching materials has focused on selecting music works. But the largest problem in front of the reform is the lack of teaching theoretical materials. The problem is the main reason of impeding the reform. Some scholars believes that under the background of new curriculum standard in full operation, teaching material construction should highlight Chinese national nature and the practical nature of teaching. Some scholars believe that vocal musical teaching material construction should highlight the function of quality education of the teaching materials.

Secondly, reform of teaching method. Main teaching methods of traditional vocal musical education are oral instruction and mechanical training, which cannot satisfy current diversified teaching contents and the requirement of new curriculum standard teaching model. Application of multimedia technology can effectively improve the defect of vocal musical teaching in high normal university. Teachers can flexibly use telegram, multimedia audio-video equipment to help teaching so as to carry out vocal musical activities from audio and auditory sense perspectives. It can effectively make the teaching class more interesting. Multimedia teaching technologies can make the content more vivid and direct, which can greatly promote the teaching efficiency. Studio art pattern can make the pure and difficult vocal musical theory more vivid and abundant for students and easy for them to memorize.

Thirdly, reform of evaluation system. Researcher Zhang Huihua believes that evaluation contents should contain signing, theoretical knowledge and teaching ability. On this basis, 6:2:2 evaluation standard is proposed. Researcher Wang Rong believes that the evaluation method of combining closed-book exam and open-book exam with oral instruction and written examination can accurately know students' comprehensive ability.

Under the background of new curriculum standard in full operation, reform of vocal musical teaching reform in high normal university should start from students, fully excavate students' potential, and also should start from vocal musical teachers. Teachers with comprehensive and systemic professional knowledge and strong teaching ability, able to master the cutting-edge dynamics of vocal musical education academic development, timely update their vocal knowledge structure and teaching method can adapt and promote the effective reform of vocal musical education in China.

\section{Conclusion}

It has been about ten years of studies on vocal musical teaching reform, and a lot of research achievements have been obtained. This has provided a correct direction and guidance for profoundly and comprehensively understand and master vocal musical teaching reform in Chinese high normal university. But limited by subjective and objective factors, there are a lot of inadequacies in research achievement such as reform is just adjustment and supplementary of vocal musical teaching curse without macro studies, etc. Based on these problems, researchers should take further exploration based on existing research achievements, keep expanding research view, combine with teaching practice and take in-depth studies from different level and dimensions so as to continuously promote sound development vocal musical education in high normal university and Chinese musical education career. 


\section{Acknowledgements}

China West Normal University Excellence Plan "Studies on vocal musical teaching reform in high normal universities" (project number: 17 YC 547).

\section{References}

[1] Wang Lei. Brief discussion on the purpose system of quality education in vocal musical specialty, Heilongjiang Science and Technology Information, 2011,09.

[2] Xu Hong Lei. Studies on vocal musical teaching reform under new curriculum background, Journal of Changchun Education Institute, 2011,07.

[3] Li Rong. Problems and reform of professional curriculum design of vocal education specialty in high normal university, Journal of Hengyang Normal University, 2011, 02.

[4] Guo Chengcheng. Brief discussion on the application and exploration of multimedia technology in vocal musical teaching in higher vocational education, Hua Zhang, 2011, 36. 